\title{
B213 食品の断面内温度分布
}

\author{
原 利次 $\bigcirc$ (日本工大) \\ 松本欣和（日本工大） \\ 工藤祐督（日本工大・学） \\ 島岡孝徳（日本工大・学）
}

\section{Radial Temperature Distribution in a Heated Food}

\author{
Toshitsugu HARA, Yoshikazu MATSUMOTO, Yusuke KUDO, Takanori SHIMAOKA
}

\begin{abstract}
Radial temperature distribution in a heated food (baked sweet potato, roasted fish and a slice of bread) was visualized by an infrared camera. The temperature distribution in those heated foods were different from predicted value when the food was heated up above 65-70 degree C. The temperature distribution at the outer part of the food was steeper than the predicted value. Temperature distribution at the inner part of the food was flattened than the predicted value.
\end{abstract}

Keywords: heat conduction, food, thermograph, temperature distribution

1.はじめに

昨年度のやき芋の加熱の研究に加えて，生体 細胞を持った食品の例として魚(アジ)と, 細胞 を持たず通気性のよい食品の例として食パン を取りあげ，この 3 種類について，加熱時の断 面内温度分布を比較して, 何故加熱後半に平坦 な温度分布が現れるのか検討した。

\section{2. 実臨装圈と测定方法}

図1に魚を加熱したときの実験装置を示す。 加熱前にあらかじめ2つに切断しておいた魚 (アジ)を, 切断面を再び元の状態に接触させ両 端から専用に製作した魚固定器で圧力をかけ て固定した。この状態の魚を，1対の平面ふく 射パネルヒータの内側中央に設置し, 両面から 加熱した。図2には側面図と上部から見た平面 図を示す。試料の魚は水平に位置される。前回 の芋の場合と同じように,一定時間ごとに断面 を手動ですばやく分割し，断面を赤外線カメラ で撮影した。撮影後分割された試料の魚は再び 組み合され，ふく射ヒータで加熱される。この ため実験中同一の魚がくり返し使用される.

図 2 に食パンを加熱したときの実験装置を示 す. 魚の加熱の場合と同様に, 食パンをスライ スした 1 枚を1対のふく射パネルヒータで両側 から加熱される。但しパンの場合は, スライス に垂直な断面を平面にするのが難しいため, 芋 や魚のように事前に分割して合せておくこと が難しい。このためパンの場合は, 測定の都度 新しいパンを用いた.すなわちすべてのパンは 加熱一定時間後切断されカメラで撮影され捨 てられる.すべての実験後異なる時間経過のパ ンの撮影写真をつなげて, 時間経過とした。こ のため複数のパンが使用された。

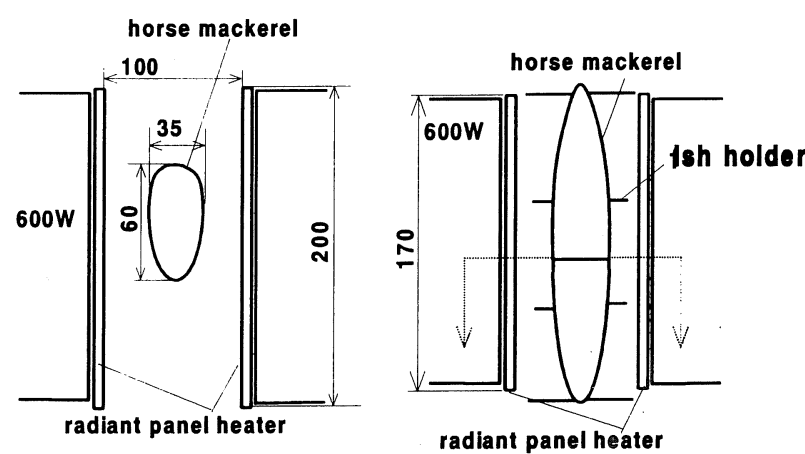

Fig.1 Experimental apparatus (fish)

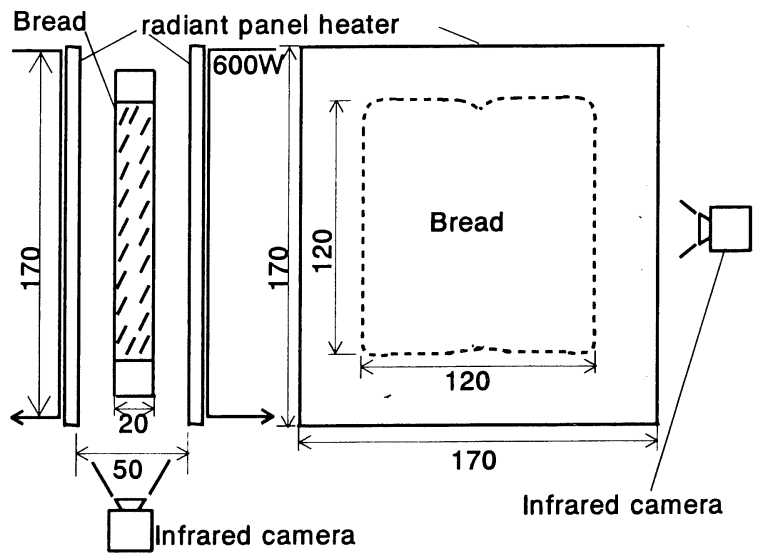

Fig.2 Experimental apparatus (bread) 


\section{2. 実験結果と検討}

図 3 に魚の場合の実験結果を示す. 図の (a) は加熱 4 分後の場合の断面内温度分布で，(b) は同様に加熱 20 分後の場合である。(a)では, 温度分布の等温線はほ ぼ断面中心を中心として等間隔で分布しており, 円 柱の非定常熱伝導として計算される結果とよく似て いる.これに対し（b)では，周辺では等温線の間隔が 狭く, 中心に近い大部分の範囲では等温線が見られ ない.これは半径方向の温度傾斜が小さく温度分布 が平坦であることを示す意味している。

図4にパンの場合の温度分布を示す. 先と同様に, 図中 (a) は加熱初期の 20 秒後の温度分布の結果であ り, (b) は加熱後期の 100 秒後の温度分布の結果を示 す.パンが変形してしまっているため厚さ方向の温 度分布が見難いが, 図の下端の温度分布を見ると,

(a)では温度分布がすり鉢上であり，（b）では中央が 平坦で周辺が急峻である傾向がわかる. パンでも魚 と同様な温度分布の変化が見られた。

温度分布の加熱時間の変化で緾めたものを, 魚に ついて図5に，パンについて図6に示す。いずれも加 熱後半に中央付近の温度分布が平坦になることがわ かる。

この原因を加熱による組成の変性時のための変性 熱と考え，変性熱を見かけの比熱の上昇として，温 度分布の実験值から逆算したものを図7に示す.比較 的変性熱のデータの傾向と一致している.
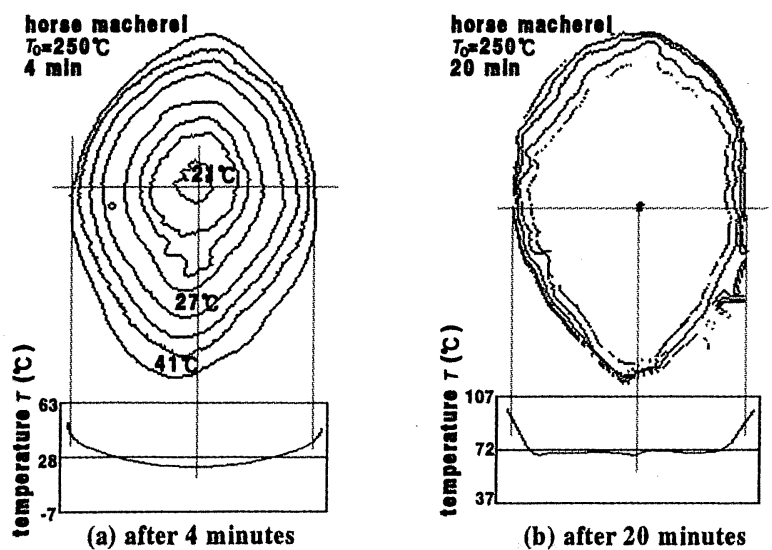

(b) after 20 minutes

Fig.3 Radial temperature distribution (horse mackerel, fish)

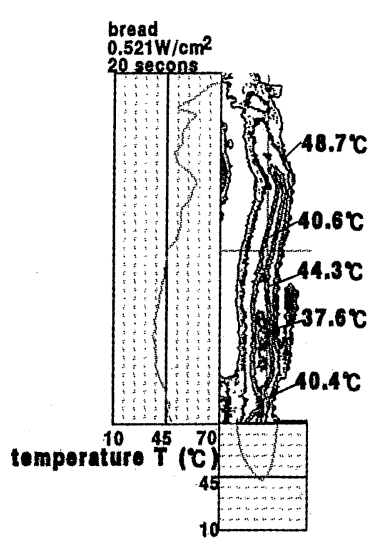

(a) after 20 seconds

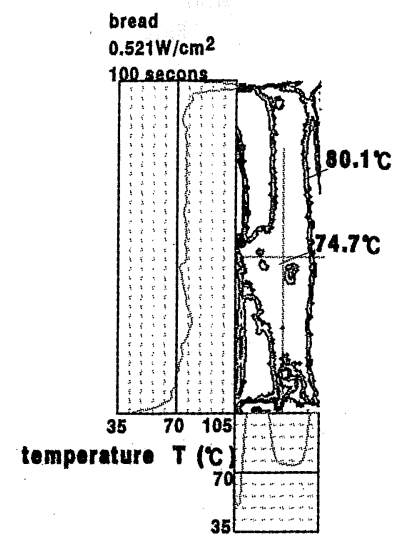

(b) after 100 seconds
Fig.4 Radial temperature distribution (slice of bread)

\section{3. 参考文献}

1) 原ほか, やき苹の断面内温度分布, 可視化情報 シンポ講演論文集 vol.20, no.1（2000） pp. 149-152.

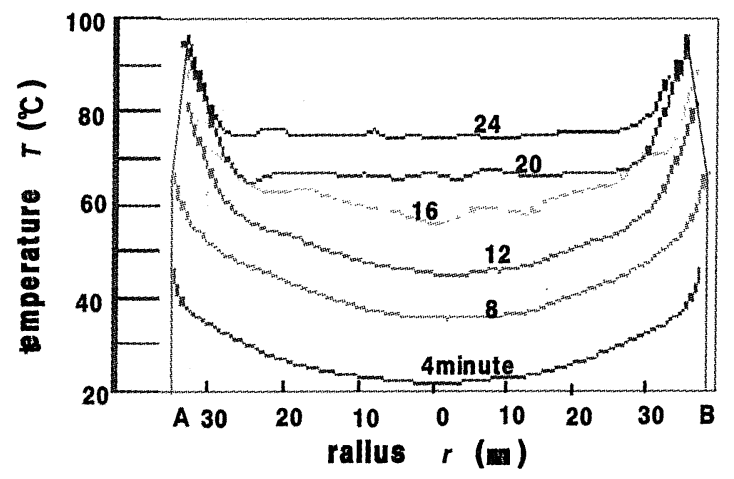

Fig.5 Change of radial temperature distribution ( horse mackerel, fish)

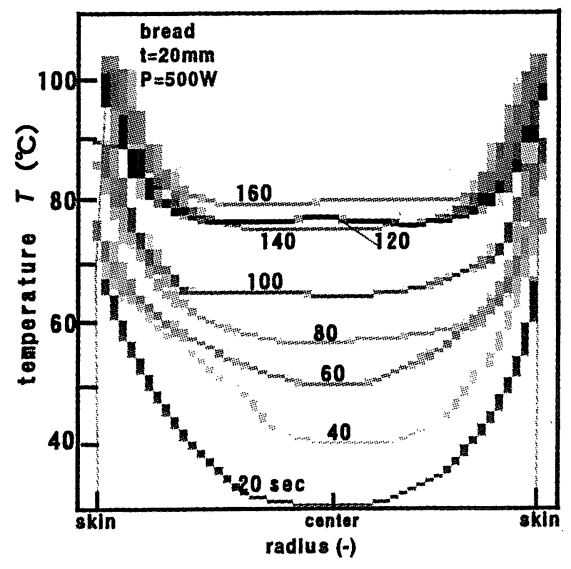

Fig.6 Change of radial temperature distribution (slice of bread)

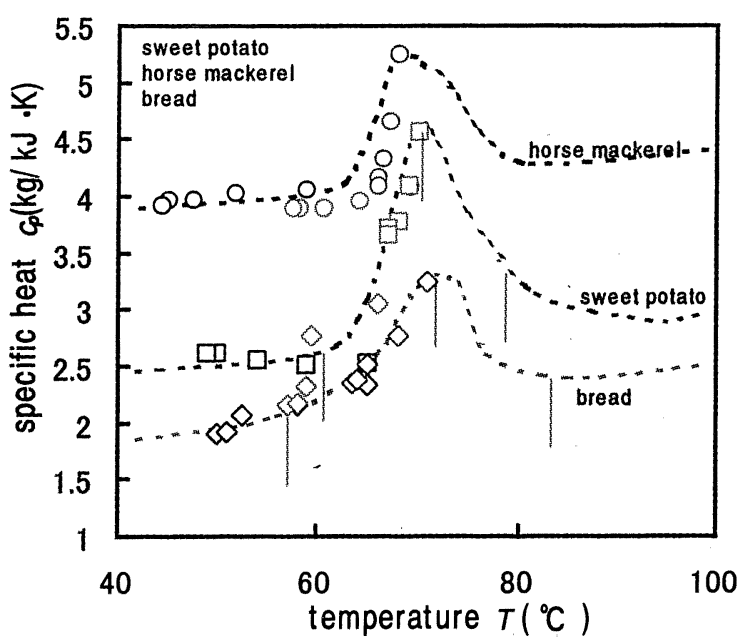

Fig.7 effective specific heat of food calculated from measured data 